\title{
Determinants of Smallholder Farmers' Participation in Banana Markets in Central Africa: The Role of Transaction Costs
}

\author{
Emily Ouma ${ }^{1}$, John Jagwe ${ }^{2}$, Gideon Obare ${ }^{3}$ and Steffen Abele ${ }^{4}$ \\ ${ }^{1}$ International Institute of Tropical Agriculture, Burundi c/o ISABU, B.P. 795 Bujumbura \\ ${ }^{2}$ Department of Agricultural Economics, Extension and Rural Development, University of Pretoria \\ (LEVLO, 002, Pretoria, South Africa) \\ ${ }^{3}$ Department of Agricultural Economics and Agribusiness Studies, Egerton University, P. O. Box 536, \\ Njoro, Kenya \\ ${ }^{4}$ International Institute of Tropical Agriculture, Tanzania, PO Box 6226, Dar es Salaam
}

\begin{abstract}
A bivariate probit model was employed to jointly and separately estimate banana market participation decisions of buying and selling households in Rwanda and Burundi using household survey data. Selectivity bias was corrected for in estimating the transacted volumes using Heckman's procedure. The results showed that transaction cost related factors such as geographical location of households, market information sources, and travel time to the nearest urban centre influence market participation. Non price related factors such as security of land tenure, labor availability, off farm income, gender of the household head and years of farming experience had a significant influence on the transacted volumes. Output prices had a significant effect on sales volume, providing incentives for increased supply by sellers. Generally, the findings suggest that policies aimed at investments in rural road infrastructure, collective marketing and value addition of banana products may provide a potential avenue for mitigating transactions costs and enhancing market participation and production of marketed surplus by rural households.
\end{abstract}

\section{JEL classification: D23, D01, D13, D71}

Keywords: smallholder farmers, market participation, transaction costs, bananas, Central Africa

\section{Introduction}

Markets and improved market access are of critical and immediate importance to rural poor households as a prerequisite for enhancing agriculture-based economic growth by improving the competitiveness of farming enterprises and improving rural incomes. Despite this, participation of smallholder farmers in domestic and regional markets in most developing countries remains low due to a range of constraints. One of the limiting constraints faced by smallholder farmers is linked to poor market access (Dorward et al. 2005; Kydd and Dorward, 2004; Makhura et al., 2001). National and international policy initiatives that aim at addressing this constraint have to address issues associated with reduction of transaction costs, which are often the embodiment of access barriers to market participation of smallholder farmers and market risks. A number of studies such as Goetz, (1992), Kranton, (1996) and Key et al. (2000) have isolated high transaction costs to be one of the key reasons for smallholder farmers' failure to participate in markets. Majority of the smallholder farmers are located in remote areas with poor 
transport and market infrastructures, contributing to the high transaction costs faced. In addition, they lack reliable market information as well as information on potential exchange partners (World Bank, 2002). In some instances, these transaction costs tend to be so high that markets can be said to be "missing" (Omamo, 1998; de Janvry et al., 1991).

Very few studies have empirically investigated the factors that influence smallholder farmers' market participation in developing countries, yet the rural smallholder farming populations form the bulk of the poor. This is in contrast to the plethora of empirical work on labor market participation. Bellemare and Barrett (2006) investigated pastoralists' market participation in livestock markets in Ethiopia and Kenya by applying an ordered tobit model to assess whether market participation and volume decisions are made simultaneously or sequentially. Goetz (1992) studied the participation of Senegalese agricultural households in grain markets using a probit model of households' discrete decision to participate in the market followed by a second stage switching regression model of the market transaction volume. Makhura et al (2001) followed the same approach to investigate smallholder farmers' participation in maize markets in the Northern Province in South Africa. Key et al (2000) developed a structural model to estimate structural supply functions and production thresholds for Mexican farmers' participation in the maize market based on a censoring model with unobserved censoring threshold. Alene et al (2008) used a sample selection model of maize marketed supply in Kenya by first estimating a probit model of maize market participation and a second stage regression model to explain maize supply among maize selling households.

These extant articles on household marketing behavior in developing countries mainly focus on market participation decision for sellers without explicitly taking into consideration the market participation decision for buyers. Yet, there may be nonindependent factors that influence the agricultural households' decision to participate in the market as sellers, buyers or to be autarkic. This paper contributes to the literature on agricultural households' market participation by investigating smallholder farmers' decision to participate in banana markets in Burundi and Rwanda by estimating jointly, the non-independent determinants of selling and buying decisions and examining the impact of market access factors on participation decision. The determinants of banana marketed quantities for participating buying and selling households have then been estimated, controlling for sample selection bias.

Bananas (Musa) play a key role in Rwanda and Burundi, contributing to rural populations' household food security and revenue. The two countries are among the twenty leading banana producers in the world with annual production estimated at 1.5 million metric tonnes in Burundi and 2.6 million metric tonnes in Rwanda (FAOSTAT, 2008). The two main banana types grown in the region include the cooking type, mainly the East African Highland Banana type which is largely produced for home consumption with surplus sold to the market, and beer banana cultivars (AB, ABB) which is a main source of household income as it is transformed into banana beer and sold to consumers. The importance of bananas to the livelihoods of the rural populations in the two countries accentuates its role as a crop whose production and marketing could be a potential pathway of improving rural livelihoods. A better understanding of the determinants of banana market access barriers, which is directly linked to transaction costs, is therefore critical in understanding why some farmers opt not to participate in markets, while others opt to participate as sellers or buyers. This would enable identification and generation of appropriate intervention measures that would enable the rural populations to benefit from 
banana markets. The remainder of the paper is structured as follows. Section 2 presents a brief highlight of the transaction cost theory. Section 3 describes the economic model while section 4 presents the empirical formulation of the market participation and supply models. Section 5 describes the data used. The empirical results are presented and discussed in section 6 . Section 7 presents concluding remarks.

\section{Transaction Cost Theory}

Transaction cost theory derives from the "New Institutional Economics" approach and focuses on institutions of governance ${ }^{1}$. It is based on the premise that institutions are transaction cost minimizing arrangements which may change and evolve with changes in the nature and sources of transaction costs (Coase, 1937; Williamson, 1985). Transaction costs, occasionally referred to as "hidden costs" are the observable and non-observable costs associated with exchange of goods and services. These costs arise due to the frictions involved in the exchange process as it entails transfer and enforcement of property rights. Past studies such as Key et al. (2000) have categorized these costs into fixed and variable transaction costs. Fixed transaction costs are invariant to the volume of output traded and affect market participation decisions of smallholder farmers. They include the costs of: (a) searching for a trading partner with whom to exchange or searching for a market (b) negotiation and bargaining particularly in the presence of imperfect price (c) screening, enforcement of contracts and supervision particularly when credit sales are involved as the sellers have to screen the buyers for reliability and lower the likelihood of defaults (Fafchamps, 2004). Variable transaction costs on the other hand are per unit costs of accessing markets that vary with the volumes traded and may affect the decision of market participation as well as quantity traded. These include costs associated with transferring the output being traded such as transportation costs and time spent to deliver the product to the market. In essence, the transactions costs raise the real price of inputs and lower the real price received for output.

\section{Theoretic Model}

The market participation model presented in this article is inspired by the economic theory of agricultural households' behavior presented in Strauss (1986) and later extended by Key et al. (2000), to incorporate both fixed and variable transaction costs. A simplified household utility is assumed to be a function of goods and services consumed specified as:

$U=\left(C ; \Delta^{c}\right)$

where $U$ is the household utility function, which is assumed to be monotone increasing in its arguments, strictly concave, and to possess continuous second partial derivatives; $C$ is the set of consumption goods and services; and the vector $\Delta^{c}$ parameterizes the utility function and summarizes individual and household characteristics as well as asset structure.

The household faces a cash constraint that states that expenditures on all purchases cannot exceed revenues from all sales and transfers. The cash constraint can be expressed to include both variable and fixed transaction costs following Key et al. (2000), as:

\footnotetext{
${ }^{1}$ Institutions of governance refer to modes of managing transactions and include market, quasi-market and hierarchical modes of contracting.
} 


$$
\sum_{i=1}^{N}\left[\left(p_{i}-t_{v i}^{s}\left(\Delta_{t}^{s}\right)\right) \zeta_{i}^{s}+\left(p_{i}+t_{v i}^{b}\left(\Delta_{t}^{b}\right)\right) \zeta_{i}^{b}\right] m_{i}-t_{f i}^{s}\left(\Delta_{t}^{s}\right) \zeta_{i}^{s}-t_{f i}^{b}\left(\Delta_{t}^{b}\right) \zeta_{i}^{b}+T=0
$$

where $p_{i}$ is the market price of good $i ; m_{i}$ represents the amount of good $i$ "marketed" and is positive if there is a sale of good $i$ and negative if there is a purchase; $\zeta_{i}^{s}$ is equal to one if $m_{i}>0$ and zero otherwise, and $\zeta_{i}^{b}$ is equal to one if $m_{i}<0$ and zero otherwise; $\Delta_{t}^{s}$ and $\Delta_{t}^{b}$ are exogenous characteristics that affect the variable transactions costs when selling $\left(t_{v i}^{s}\right)$ and buying $\left(t_{v i}^{b}\right)$ respectively. The variable transactions costs raise the price effectively paid by a buyer and lower the price effectively received by a seller. The price effectively received by the seller is lower than the market price $p_{i}$, by the unobservable amount, $t_{v i}^{s}$, and the price effectively paid by the buyer is greater than $p_{i}$ by the unobservable amount $t_{v i}^{b} ; t_{f i}^{s}$ and $t_{f i}^{b}$ are the unobservable fixed transactions costs when selling and buying good $i$ respectively and are a function of the observable exogenous factors $\Delta_{t}^{s}$ and $\Delta_{t}^{b}$ that can explain these costs; and $T$ is exogenous transfers and other incomes.

The technology of farm production is represented by a twice differentiable concave production function;

$G\left(Y_{i}, X_{i} ; \Delta^{2}, M, \Omega\right)$

where $Y_{i}$ is amount of output $i$ produced from the farm, $X_{i}$ represents both purchased and non-purchased inputs used in the production process of good $i$. Vector $\Delta^{z}$ represents household characteristics affecting production decisions, $M$ is a vector of fixed factors such as land, and $\Omega$ is a vector of fixed effects of location, such as population density and market access.

The household also faces a resource balance constraint presented as:

$Y_{i}-X_{i}+A_{i}-m_{i}-C_{i}=0$,

where $A_{i}$ is the endowment of good $i$. The resource balance equation in (4) states that the amount consumed, $C_{i}$, used as input, $X_{i}$ and sold, $\left(m_{i}>0\right)$ is equal to what is produced, $Y_{i}$ and bought plus the endowment, $A_{i}$ of the good. Since output $\left(Y_{i}\right)$, inputs $\left(X_{i}\right)$ or consumption $\left(C_{i}\right)$ of a good $i$ may be zero in a given production cycle but not less than zero, a non-negativity constraint is imposed;

$C_{i}, Y_{i}, X_{i} \geq 0$

The decision problem is to choose whether or not to participate in the product market and the product quantity in order to maximize household welfare given the fixed and variable transactions costs faced by the household. This can be restated formally as;

$$
\begin{aligned}
L & =U\left(C_{i} ; \Delta^{c}\right)+\sum_{i=1}^{N} \eta_{i}\left(Y_{i}-X_{i}+A_{i}-m_{i}-C_{i}\right)+\psi\left(G\left(Y_{i}, X_{i} ; \Delta^{z}, M, \Omega\right)\right) \\
& +\lambda\left[\sum_{i=1}^{N}\left[\left(p_{i}-t_{v i}^{s}\right) \zeta_{i}^{s}+\left(p_{i}+t_{v i}^{b}\right) \zeta_{i}^{b}\right] m_{i}-t_{f i}^{s} \zeta_{i}^{s}-t_{f i}^{b} \zeta_{i}^{b}+T\right]
\end{aligned}
$$


where $\eta_{i}, \psi$ and $\lambda$ are the Lagrangian multipliers associated with the resource balance, technology constraint on farm production and cash constraint respectively. Maximization of this Lagrange with respect to the marketed goods would result in discontinuities due to the fixed transactions costs. The optimal solution for the Lagrange function is therefore decomposed into two steps; first solving for the optimal solution conditional on the market participation regime, secondly choosing the market participation regime that yields the highest level of utility. The first step involves maximization of the Lagrangian function with respect to consumption goods $C_{i}$, outputs $Y_{i}$, inputs $X_{i}$ and the marketed goods $m_{i}$, yielding the following first order conditions;

$\partial U / \partial C_{i}-\eta_{i}=0$

$\eta_{i}+\psi \partial G / \partial Y_{i}=0$

$-\eta_{i}+\psi \partial G / \partial X_{i}=0$

$-\eta_{i}+\lambda\left[\left(p_{i}-t_{v i}^{s}\right) \zeta_{i}^{s}+\left(p_{i}+t_{v i}^{b}\right) \zeta_{i}^{b}\right]=0 \quad i \in\left\{i \mid m_{i} \neq 0\right\}$

Based on equation 10, the market participation decision price can then be defined thus;

$$
p_{i}=\left\{\begin{array}{l}
p_{i}-t_{v i}^{s} \quad \text { if } m_{i}>0, \quad \text { seller } \\
p_{i}+t_{v i}^{b} \quad \text { if } m_{i}<0, \quad \text { buyer } \\
\hat{p}_{i}=\eta_{i} / \lambda \quad \text { if self - sufficient / autarkic. }
\end{array}\right.
$$

When good $i$ is marketed, the decision price includes the variable transactions costs, $t_{v i}^{s}$ or $t_{v i}^{b}$. However, when the good is not marketed, the decision price becomes an unobservable internal shadow price, $\eta_{i} / \lambda$. The household's market participation decision under conditions of variable and fixed transactions costs is taken as a choice decision, where the household is assumed to weigh up its expected utility under the three regimes presented in equation 11 and choose the one associated with the highest utility. The utility levels to be compared under the three different regimes can be presented in the form of indirect utility functions;

$$
\begin{array}{ll}
V^{s}=V_{i}\left(p_{i}-t_{v i}^{s}, y_{0}\left(p_{i}-t_{v i}^{s}\right)-t_{f i}^{s}, \Delta^{c}\right) & \text { if seller } \\
V^{b}=V_{i}\left(p_{i}+t_{v i}^{b}, y_{0}\left(p_{i}+t_{v i}^{b}\right)-t_{f i}^{b}, \Delta^{c}\right) & \text { if buyer } \\
V^{a}=V_{i}\left(\hat{p}_{i}, y_{0}\left(\hat{p}_{i}\right), \Delta^{c}\right) & \text { if autarkic }
\end{array}
$$

where $y_{0}$ is the household income at the decision price $p$ of good $i$ before incurring the fixed transactions cost, $t_{f i}$. The optimal market participation for a household is to buy when the market prices are below $p_{i}-t_{v i}^{b}$, be autarkic when $p_{i}-t_{v i}^{b}<p_{i}<p_{i}+t_{v i}^{s}$ and sell when market prices are above $p_{i}+t_{v i}^{s}$. An increase in the fixed transactions costs directly lowers household income and utility.

The corresponding supply function for good $i$ with transactions costs can be presented as; 


$$
\begin{aligned}
& q_{i}^{s}=q\left(p_{i}+t_{v i}^{s}, \Delta^{z}, M, \Omega\right) \quad \text { for sellers } \\
& q_{i}^{b}=q\left(p_{i}-t_{v i}^{s}, \Delta^{z}, M, \Omega\right) \quad \text { for buyers } \\
& q^{a}=q\left(\hat{p}_{i}, \Delta^{z}, M, \Omega\right) \quad \text { autarkic households }
\end{aligned}
$$

The fixed transactions costs do not affect the supply curve but affects the market participation decision. It is assumed that once the household makes the decision to participate in the markets either as a buyer or seller, then only the marginal return to production affects supply decisions. With fixed transactions costs, entry into the market as a seller is delayed until the decision price is sufficiently high to compensate for the fixed transactions costs. On the other hand, entry into the market as a buyer is delayed until the market price is sufficiently low.

\section{Econometric Estimation}

The econometric specification of the preceding model consists of market participation decision equations and banana supply equations estimated separately for buyers $(i=1)$ and sellers $(i=2)$. It is assumed that the market participation decision (either as a seller or buyer) in a given season is mutually exclusive from the households' perspective. The mutual exclusivity assumption renders the participation decision as a set of discrete choices. For instance, a seller satisfies the condition to be a seller but does not satisfy the condition to be a buyer or autarkic and vice-versa in a given season. This also conforms to the data used as there is no single household that is both selling and purchasing bananas in a given season. Equations 12 and 13 show that market participation depends on both fixed and variable transactions costs while the supply or demand decision, conditional on market participation only depends on the variable transactions costs. Using $q_{i}^{s}$ to denote quantity sold by households and from equation 12, a set of structural equations can be envisioned to assess the market participation theoretical model and an empirical probability model. It follows that;

$$
\begin{aligned}
& q_{i}^{s}>0 \Leftrightarrow E\left[V^{s}\left(p_{i}-t_{v i}^{s}, y_{0}\left(p_{i}-t_{v i}^{s}\right)-t_{f i}^{s}, \Delta^{c}\right)\right]-E\left[V^{n}\left(p_{n}, y_{0}\left(p_{n}\right), \Delta^{c}\right)\right]>0 \\
& q_{i}^{s}=0 \text { otherwise }
\end{aligned}
$$

That is, the household banana market supply quantity is greater than 0 if the expected utility associated with market participation as a seller is greater than the expected utility associated with the $n$ alternatives, that is, being a buyer or autarkic after the evaluation of each of the alternatives.

Similarly for buyers,

$$
\begin{aligned}
& q_{i}^{b}>0 \Leftrightarrow E\left[V^{b}\left(p_{i}+t_{v i}^{b}, y_{0}\left(p_{i}+t_{v i}^{b}\right)-t_{f i}^{b}, \Delta^{c}\right)\right]-E\left[V^{n}\left(p_{n}, y_{0}\left(p_{n}\right), \Delta^{c}\right)\right]>0 \\
& q_{i}^{b}=0 \text { otherwise }
\end{aligned}
$$

For the reduced form estimation of the probability model, a linear expression of utility is assumed;

$$
\begin{aligned}
V_{i}^{a} & =\beta_{1} X_{i 1}+\mu_{i 1} \\
V_{i}^{n} & =\beta_{n} X_{i n}+\mu_{i n}
\end{aligned}
$$


where the $X_{i n}$ are the exogenous explanatory variables in equation $14, V_{i}^{a}$ is the utility associated with market participation either as a seller or buyer and $\mu_{\text {in }}$ are random disturbance terms for the population of buyer, seller and autarkic households. A market participation indicator variable $\left(Z_{i}^{*}\right)$ for individual $i$ can be defined as:

$Z_{i}^{*}=1$ if $V_{i}^{a}>V_{i}^{n}$

and

$$
Z_{i}^{*}=0 \text { if } V^{a} \leq V_{i}^{n}
$$

Since $\mu_{i 1}$ and $\mu_{\text {in }}$ are random variables, the probability of market participation can then be specified as;

$$
\begin{aligned}
\operatorname{pr}\left(Z_{i}^{*}\right. & =1)=\operatorname{pr}\left(V_{i}^{a}>V_{i}^{n}\right) \\
& =\operatorname{pr}\left(\beta_{1} X_{i 1}-\beta_{n} X_{i n}\right)<\operatorname{pr}\left(\mu_{\text {in }}-\mu_{i 1}\right) \\
& =F_{v}\left(\beta X_{i}\right)
\end{aligned}
$$

where $v=\mu_{\text {in }}-\mu_{i 1}, \beta X_{i}=\beta_{1} X_{i 1}-\beta_{n} X_{i n}$, and $F($.$) is a cumulative distribution function$ for the random variable $v$.

In this article, the reduced-form household banana market supply or demand functions have been specified as a semilog model;

$\ln q_{i}^{a}=\gamma X_{i}+\varepsilon_{i} \quad i=1,2$

The vector $X$ represents the independent variables specified on the right-hand side of equation (13); $\beta$, and $\gamma$ are vectors of parameters to be estimated. The error terms, $\mu_{i}$, and $\varepsilon_{i}$ are assumed to be joint-normally distributed with zero means and finite variances.

Application of OLS to the household banana market supply or demand function to estimate the $\gamma$ coefficients in equation (18) would yield biased parameter estimates since they do not take into account the process generating the observed market quantities of households. A Lee-Heckman type two-step process has therefore been applied to correct for the possibility of bias due to sample selection (Heckman, 1979; Maddala, 1983). The model is estimated using an extension of the Heckman two-step procedure. The first step involves the estimation of the relationships in equation (17) using a bivariate probit model. This provides estimates of joint probabilities of market participation for buyers and sellers and provides estimates of $\beta$ and $\rho$, which is the correlation between errors. These estimates are then used to calculate the inverse Mills ratios $(\lambda)$, which is then added to the market supply and demand functions in equation (18). This process yields the following equation which can be estimated by OLS free of selection bias. The structural household banana market supply and demand functions take the form;

$$
\ln q_{i}^{a}=\gamma X_{i}+\sigma_{i} \lambda_{i}+\varepsilon_{i}^{*} \quad i=1,2
$$

where $\lambda_{i}=\phi(\beta X) / \Phi(\beta X)$ if $Z_{i}=1$, and $\lambda_{i}=-\phi(\beta X) /(1-\Phi(\beta X))$ if $Z_{i}=0$, and $\phi$ and $\Phi$ are the probability density and cumulative distribution functions of the normal 
distribution respectively. The coefficients on the variable $\lambda_{i}$ in the household banana market supply equation provide estimates of the covariance between the errors in the selectivity equation (17) and the market supply equation, that is, $\sigma_{i}=\operatorname{cov}\left(\varepsilon_{i}^{*} \mu\right)$.

The banana market participation decision given in equations (16a) and (16b) are assumed to be non-separable, within a utility maximization framework. The probability of a household participating in the market as a buyer is affected by the characteristics of participation as a seller particularly in terms of the transactions costs involved and viceversa. Participation decisions are affected by random shocks to household banana market supply and demand; the correlation between the shocks $(\rho)$ is positive if the sellers and buyers are similarly affected by the shocks (Goetz, 1992). The t-statistic on the parameter $\hat{\rho}$ is a Wald test of the hypothesis that $\rho$ equals zero. Statistical significance of the correlation between the error terms in the equation would imply that a full information maximum likelihood bivariate probit should be used, as opposed to univariate probit estimation.

\section{Data Description}

The data used in the present analysis were collected between June and November 2006 in Rwanda and Burundi. Five communes of Gitega, Kirundo and Cibitoke provinces were covered in Burundi while in Rwanda, seven districts of Est, Ouest and Sud provinces were covered. A random sample of fifty to one hundred farm households was selected from each of the communes and districts yielding a total sample size of one thousand, four hundred and five households. Information from these households was gathered through questionnaire interviews. The questionnaire covered a range of topics including household systems and socio-economic structures, farming system agronomics, access to markets and marketing patterns of the focus crops, post harvest handling and processing of the focus crops, social structure of the households and households' embedding in social structures within the sites, status and determinants of food security, and health and nutritional status of the household. The questionnaire design and development was carried out by lead scientists of the Consortium for Improving Agriculture-based Livelihoods in Central Africa (CIALCA) project while data collection was done by fully trained enumerators speaking the local language. Additional data used was obtained from GIS - derived measures of location and distance to markets in order to better understand the market access effects particularly as it relates to variable transaction costs. All the surveyed households were geo-referenced, making it possible to derive the GIS measures. Table 1 presents the definitions and sample statistics for the variables used in the bivariate probit and OLS estimations. 
Table 1: Data definitions and descriptive statistics

\begin{tabular}{|c|c|c|c|}
\hline Variable & Variable Description & $\begin{array}{l}\text { Sample } \\
\text { Mean }\end{array}$ & S.D. \\
\hline \multicolumn{4}{|c|}{ Independent Variables } \\
\hline BICYCLE_CAR & 1 if the household owns a bicycle or a car & 0.38 & 0.48 \\
\hline ACCESS & Time taken to reach the nearest urban market in hrs & 3.08 & 2.76 \\
\hline CHILD5 & $\begin{array}{l}\text { Number of children household members } 5 \text { years old and } \\
\text { below }\end{array}$ & 1.18 & 1.08 \\
\hline CHILD17 & $\begin{array}{l}\text { Number of children household members b/w } 6 \text { and } 17 \text { years } \\
\text { old }\end{array}$ & 2.18 & 1.86 \\
\hline ONFARM_M & $\begin{array}{l}\text { Number of active male household members b/w } 18-59 \text { years } \\
\text { full time on-farm. }\end{array}$ & 0.74 & 0.67 \\
\hline ONFARM_W & $\begin{array}{l}\text { Number of active female household members b/w } 18-59 \text { years } \\
\text { full time on-farm. }\end{array}$ & 0.86 & 0.79 \\
\hline OLDMEM & Number of adult members more than 59 years old & 0.16 & 0.46 \\
\hline ADULTS & $\begin{array}{l}\text { Total number of female and male members b/w } 18-59 \text { years } \\
\text { full time on-farm }\end{array}$ & 1.60 & 1.11 \\
\hline FSIZE & Average total land size in ha & 2.72 & 8.30 \\
\hline CREDIT & 1 if the household has obtained credit in $2005-06$ & 0.21 & 0.41 \\
\hline OFF_FARM & 1 if household has access to off farm income & 0.43 & 0.49 \\
\hline FEMH_WID & 1 if the household is female headed & 0.17 & 0.38 \\
\hline FARMGATE & 1 if market outlet is farm gate & 0.24 & 0.42 \\
\hline URBANMKT & 1 if market outlet is big urban or regional market & 0.11 & 0.32 \\
\hline INF_TRADER & 1 if source of price information is traders & 0.29 & 0.45 \\
\hline INF_MEDIA & 1 if source of price information is media & 0.07 & 0.26 \\
\hline INF_NEIGH & 1 if source of price information is neighbor & 0.21 & 0.41 \\
\hline INF_MARKET & 1 if source of price information is market & 0.43 & 0.49 \\
\hline MEMFARM & 1 if household is a member of a farmer group & 0.29 & 0.46 \\
\hline RADIO & 1 if the household owns a radio & 0.69 & 0.46 \\
\hline CIBITOKE & $\begin{array}{l}1 \text { if household resides in Cibitoke province } \\
\text { (Mugina commune) }\end{array}$ & 0.07 & 0.25 \\
\hline GITEGA & $\begin{array}{l}1 \text { if household resides in Gitega province } \\
\text { (Giheta and Mutaho communes) }\end{array}$ & 0.14 & 0.34 \\
\hline KIRUNDO & $\begin{array}{l}1 \text { if household resides in Kirundo province } \\
\text { (Busoni and Kirundo communes) }\end{array}$ & 0.14 & 0.35 \\
\hline EST & $\begin{array}{l}1 \text { if household resides in Est province } \\
\text { (Bugesera, Kibungo and Umutara districts) }\end{array}$ & 0.43 & 0.49 \\
\hline OUEST & $\begin{array}{l}1 \text { if household resides in Ouest province } \\
\text { (Kibuye, Cyangugu and Gisenyi districts) }\end{array}$ & 0.14 & 0.35 \\
\hline SUD & $\begin{array}{l}1 \text { if household resides in Sud province } \\
\text { (Gitarama district) }\end{array}$ & 0.07 & 0.25 \\
\hline BEERBANPRI & Price per Kg of beer banana (US\$) ${ }^{\mathrm{a}}$ & 0.20 & 0.18 \\
\hline COOKBANPRI & Price per Kg of cooking banana (US\$) ${ }^{\mathrm{a}}$ & 0.23 & 0.47 \\
\hline YRSEXP & Number of years of farming experience & 17.8 & 12.6 \\
\hline SOILWAT & $\begin{array}{l}1 \text { if household carries out soil and water conservation } \\
\text { measures }\end{array}$ & 0.90 & 0.29 \\
\hline PUR_HIR & 1 if the land tenure system is freehold or rental & 0.31 & 0.46 \\
\hline TLU_TOT & Tropical Livestock Units (TLU) & 0.07 & 0.47 \\
\hline \multicolumn{4}{|c|}{ Dependent variables } \\
\hline $\mathrm{S}_{1}$ & 1 if household participates in the market as a seller & 0.47 & 0.49 \\
\hline $\mathrm{S}_{2}$ & 1 if household participates in the market as a buyer & 0.39 & 0.49 \\
\hline $\mathrm{Q}_{1}$ & $\begin{array}{l}\text { Logarithm of total amount in } \mathrm{Kg} \text { sold in the market by banana } \\
\text { selling households }{ }^{\mathrm{b}} \text {. }\end{array}$ & 5.32 & 1.58 \\
\hline $\mathrm{Q}_{2}$ & $\begin{array}{l}\text { Logarithm of total amount in } \mathrm{Kg} \text { bought from the market by } \\
\text { banana buying households }{ }^{\mathrm{b}} \text {. }\end{array}$ & 1.68 & 1.17 \\
\hline
\end{tabular}

\footnotetext{
${ }^{\mathrm{a}}$ Average annual 2006 dollar rates used - $1 \mathrm{US} \$=1059.1 \mathrm{FBU}$ and 549.9RWF.

${ }^{\mathrm{b}}$ Calculated for only those who participated in the banana markets.
} 
The model specifications were estimated using LIMDEP econometric software package, version 8. The independent variables include the set of standard variables theoretically expected to influence market participation decision and quantities traded. A number of variables have been included to proxy fixed and variable transactions costs. Dummy variables for car, motorcycle or bicycle ownership have been included to assess households' transportation ease to the market. Access to transportation equipment reduces the costs associated with transportation and is therefore expected to positively influence market participation. The variable for time taken to reach the nearest urban centre has been used to proxy the state of the road infrastructure and market access ${ }^{2}$. Areas closer to urban areas form large demand centers offering lucrative prices while declines in the cost of market information and transport flows due to good road infrastructure reduce transaction costs. The age variables, CHILD5, CHILD17 and OLDMEM are hypothesized to influence the fixed costs of market participation. The older and more experienced members have greater and repeated contacts, which may enhance mutual trust and allow trading opportunities to be undertaken at lower costs (Goetz, 1992). The number of children less than six years of age and those above six has been included to indicate the number of dependants, a factor that may influence household market participation direction as seller or buyer since the number of dependants is expected to influence the household marketed surplus.

Dummy variables for market outlets mainly used by households for their agricultural produce have been used to proxy both variable and fixed transactions costs. Selling to a local or large urban market compared to farm gate is expected to be associated with better market prices and consequently is assumed to stimulate marketed production and by implication, decrease the variable transactions costs associated with sales (Minten and Kyle, 1999). However, the fixed cost factors such as distance to these market outlets would influence market participation. Unfortunately, due to the survey design, information on distances to the local markets was not gathered. This limitation is partly overcome by the travel time variable to the nearest large urban centre.

Price information source dummy variables have been included to also represent fixed cost type transactions costs. Access to price information is hypothesized to play a significant positive role in influencing market participation (Chowdhury, 2002). The summary statistics show that the main source of price information is the market. Forty three percent of the households indicate obtaining price information from the market compared to 21 and 7 percent who indicate their price information source to be neighbors and the media respectively. The variables for ownership of a radio and membership to farmer groups have also been included to proxy market information sources.

Other variables such as total land size, access to formal credit and number of male and female household members between 18-59 years of age indicate access to production enhancing assets which would influence the production of a marketable surplus. The average household total land size is 2.7 ha though the variation is quite large across households as is evident in the large standard deviation of 8.3. The variable for number of male and female household members between 18-59 years of age indicates the household labor self sufficiency which has a positive influence on both banana production and participation in banana markets. Access to off farm income is a wealth indicator which can be viewed on one hand as positively influencing production, and on the other as influencing the direction of market participation as a buyer since it increases a

\footnotetext{
${ }^{2}$ For each survey site, the nearest urban markets were chosen for calculating the accessibility indicators.
} 
households' purchasing power. Its expected sign in the model is therefore ambiguous. The variable for gender of the household head influences market participation and market volume as it is linked to financial and labor resources access. An individual household's province of residence may also be a determining factor in market participation decisions and market volumes, as it reflects among other things, the agro-climatic conditions as well as the local market pricing conditions.

The banana prices, both cooking and beer banana influence the supply or demand quantities by households. A positive relationship is expected for the selling households and a negative one for the buying households following the theory of consumer behavior. Other production enhancing variables that have been included in the model are land tenure security of the household, tropical livestock units and presence of soil and water conservation structures. The security of land tenure is a wealth indicator and also influences the production objective function and types of initiatives that a household would undertake (Hayes et al., 1997). It is hypothesized to have a positive relationship with production of a marketable surplus. A similar relationship is hypothesized for the tropical livestock unit variable ${ }^{3}$. This indicates the total number of livestock units owned by a household. The average number of livestock units owned per sample household is only 0.07 , representing about one livestock unit per household. It is assumed that households with livestock use manure to fertilize agricultural plots, thereby increasing production.

\section{Empirical Results}

\section{Market participation decision}

Table 2 presents the results of the maximum likelihood bivariate probit estimates of the equations explaining the probability of households to participate in banana marketing. The estimate of $\rho$ (correlation between the errors) that maximized the bivariate probit function is -0.224 and is significantly different greater than zero at the $1 \%$ level. This suggests that the random disturbances in the banana market participation decisions of sellers and buyers are affected in opposite directions by random shocks and that their participation decisions are not statistically independent. Consequently, inefficient parameter estimates may be obtained if the equations are estimated separately.

The sample value of the likelihood ratio is 324.4 with a critical value of $\chi_{21,0.01}^{2}=4.02$ is statistically significant at the $1 \%$ level suggesting that the independent variables taken together influence market participation decisions. The results suggest that ownership of a bicycle or a car by a household reduces the probability of market participation as a seller, which seems counter-intuitive. Only $38 \%$ of the sample households own at least one bicycle. A plausible explanation is that ownership of a bicycle or a car is considered an asset for the wealthier households who could be participating less in the banana markets. Results from other surveys in the region reveal that most smallholder farmers travel to the market on foot, physically carrying goods on their head or back. An increase in time taken to reach the nearest urban centre decreases the probability of market participation for sellers and buyers, a result consistent with findings based on Senegal data (Goetz, 1992). This reinforces the argument that poor market access for households located in remote areas raises costs associated with marketing and information. The coefficient for

\footnotetext{
${ }^{3} 1$ Tropical Livestock Unit is refers to a $250 \mathrm{Kg}$ live weight animal. The following conversions have been used: 1 cattle (cow/bull) is equivalent to 1 TLU while 1 small ruminant is equivalent to 0.12 (ILCA, 1990 pg 129).
} 
number of household members between the ages of 6 and 17 had a negative sign and significantly different from zero in the equation for buyers but was not statistically significant in the sellers equation. This age group category does not have strong purchasing power to enable them participate in the market as buyers but contribute to onfarm family labor supply particularly during non-school going periods, thereby influencing the marketable surplus production.

Table 2: Bivariate Probit Estimates of Market Participation Equations of Banana Sellers and Buyers

\begin{tabular}{|c|c|c|c|c|c|c|}
\hline \multirow{2}{*}{ Variable } & \multirow{2}{*}{$\begin{array}{l}\text { Sellers } \\
\text { Coefficient }\end{array}$} & \multirow[b]{2}{*}{$\begin{array}{l}\text { Standard } \\
\text { Error }\end{array}$} & \multirow[b]{2}{*}{$\begin{array}{l}\text { Marginal } \\
\text { Probability }\end{array}$} & \multirow{2}{*}{$\begin{array}{l}\text { Buyers } \\
\text { Coefficient }\end{array}$} & \multirow[b]{2}{*}{$\begin{array}{l}\text { Standard } \\
\text { Error }\end{array}$} & \multirow[b]{2}{*}{$\begin{array}{l}\text { Marginal } \\
\text { Probability }\end{array}$} \\
\hline & & & & & & \\
\hline INTERCEPT & 0.056 & 0.140 & - & -0.087 & 0.129 & - \\
\hline BICYCLE_CAR & $-0.159^{* *}$ & 0.083 & -0.063 & -0.074 & 0.080 & -0.005 \\
\hline ACCESS & $-0.002^{* * *}$ & 0.000 & -0.001 & $-0.000^{* * *}$ & 0.000 & -0.000 \\
\hline CHILD5 & -0.054 & 0.037 & -0.021 & 0.005 & 0.034 & 0.000 \\
\hline CHILD17 & 0.007 & 0.020 & 0.003 & $-0.057^{* * *}$ & 0.022 & -0.004 \\
\hline ONFARM_M & 0.057 & 0.059 & 0.023 & -0.047 & 0.056 & -0.003 \\
\hline ONFARM_W & -0.018 & 0.050 & -0.007 & 0.043 & 0.048 & 0.003 \\
\hline OLDMEM & -0.010 & 0.081 & -0.004 & 0.062 & 0.075 & 0.004 \\
\hline FSIZE & $0.009^{*}$ & 0.005 & 0.004 & 0.000 & 0.000 & 0.000 \\
\hline CREDIT & -0.029 & 0.091 & -0.011 & 0.130 & 0.088 & 0.008 \\
\hline OFF_FARM & 0.008 & 0.077 & 0.003 & $0.150^{* *}$ & 0.074 & 0.009 \\
\hline FEMH_WID & $-0.215^{* *}$ & 0.109 & -0.084 & 0.000 & 0.001 & -0.000 \\
\hline FARMGATE & 0.092 & 0.068 & 0.036 & 0.066 & 0.065 & 0.004 \\
\hline URBANMKT & -0.092 & 0.068 & -0.036 & -0.066 & 0.065 & -0.004 \\
\hline INF_NEIGH & -0.060 & 0.074 & -0.024 & $-0.246^{* * *}$ & 0.075 & -0.015 \\
\hline INF_MARKET & $0.136^{* *}$ & 0.063 & 0.053 & 0.055 & 0.061 & 0.003 \\
\hline MEMFARM & 0.053 & 0.083 & 0.021 & -0.040 & 0.078 & -0.003 \\
\hline RADIO & 0.078 & 0.086 & 0.031 & -0.038 & 0.082 & -0.002 \\
\hline CIBITOKE & $0.407^{* * *}$ & 0.158 & 0.160 & $-0.359^{* *}$ & 0.163 & -0.022 \\
\hline KIRUNDO & $-0.265^{*}$ & 0.151 & -0.104 & -0.093 & 0.137 & -0.006 \\
\hline EST & -0.126 & 0.096 & 0.049 & -0.136 & 0.095 & -0.008 \\
\hline OUEST & $0.607^{* * *}$ & 0.130 & 0.239 & $-0.275^{* *}$ & 0.127 & -0.017 \\
\hline \multicolumn{2}{|c|}{ Log-likelihood function } & -1732.07 & & & & \\
\hline \multirow{2}{*}{\multicolumn{2}{|c|}{$\mathrm{RHO}(1,2)$}} & $-0.224^{* * *}$ & & & & \\
\hline & & $(0.045)^{\mathrm{b}}$ & & & & \\
\hline \multicolumn{2}{|c|}{ Log-likelihood ratio } & 324.4 & & & & \\
\hline
\end{tabular}

Note: ${ }^{* * *}$ and ${ }^{* * *}$ denote significance at the 10,5 and $10 \%$ level. The Log-likelihood ratio test is given by $2\left(L_{u}-L_{w}\right)$ and is asymptotically distributed as a $\chi^{2}$ with 21 degrees of freedom.

${ }^{\mathrm{b}}$ Standard error in parenthesis

The results also show that larger land sizes raise the probability of market participation for sellers. This is expected since land is a critical production asset having a direct bearing on production of a marketable surplus, ceteris paribus. Access to off farm income increases the likelihood of banana market participation for buyers. This finding is consistent with those found in agricultural product market participation studies of other countries (Alene et al., 2008). Off farm income raises a household's purchasing power, and particularly when labor is a constraining factor, households are forced to weigh between on-farm production and off farm income. This is also in line with findings by 
Fafchamps and Hill (2005) that show that wealthy farmers in Uganda are less likely to sell their coffee produce to the market possibly because the shadow value of their time is higher than the poorer households. The gender of the head of the household has a significant impact in the market participation decision. There is a lower likelihood of market participation as sellers for female headed households but is not statistically significant for the buyers' equation. A plausible explanation for this is that female headed households are resource constrained, thereby affecting production of a marketable surplus ${ }^{4}$. Moreover, female headed households are more likely to be concerned about securing food for the family such that subsistence oriented agriculture would be pronounced for such households. To assess the link between labor resource and gender of the head of the household, a multiplicative interaction term between gender of the household head and number of adult members in the household was introduced in the model. However, this did not yield statistically significant results and was eventually dropped.

The coefficients for market outlet variables in the equations for both buyers and sellers were not significantly different from zero. Market price information variables produced varying results for both buyers and sellers. Market as a source of price information increases the likelihood of market participation for sellers while neighbors as a source of price information reduce the probability of market participation for buyers. Ownership of radios turned out to be statistically insignificant in influencing market participation for both sellers and buyers. This is possibly because communication assets are less useful in accessing market information and in facilitating transactions in the region. In Burundi and Rwanda, agricultural production price information is not commonly published in newspapers or announced in the electronic media. In the rare cases when this is done, the focus is only for major markets which may not be accessible to farmers. Alene et al (2008) find similar results in their study of maize market participation in Kenya.

The fixed effects location variables are significant in explaining banana market participation. Gitega and Sud provinces were left out of the model for Burundi and Rwanda respectively to avoid the dummy variable trap. The results indicate that households in Cibitoke province are more likely to participate in the banana market as sellers than buyers relative to those in Gitega province. The marginal effect for Cibitoke household participation for sellers is 0.16 compared to -0.02 for buyers. Cibitoke is a high banana production area in Burundi, particularly for beer bananas which are transformed into banana wine mainly used as a source of household revenue. Conversely, households in Kirundo province are less likely to participate in the market as sellers compared to those in Gitega province, possibly because of differential market access across the two provinces (Andy et al., 2006). For Rwanda, households in the Ouest province are more likely to participate in the markets as sellers and less likely to participate as buyers relative to those in Sud province. Location of a household in the Ouest province raises the probability of market participation as a seller by $24 \%$. The coefficient for Est province is negative but statistically insignificant. In Rwanda, high production areas particularly for beer bananas are in the Ouest province such as Cyangugu district while cooking bananas are prominent in the Est province in Kibungo and Gitarama districts (Gaidashova et al., 2005). This result for both countries indicate

\footnotetext{
${ }^{4}$ Most female headed households lack access to productive assets (land, labor, capital) thereby limiting their production capabilities.
} 
that production and selling decisions are linked to comparative advantage in production. Households in beer banana production zones are more likely to participate in the markets as sellers than those from cooking banana zones. This is not entirely unexpected since the juice or beer extracted and processed from beer bananas are largely used for income generation while the cooking bananas are used for home consumption and surplus traded in the market.

\section{Banana Supply and Demand Functions}

Table 3 presents the results of the banana supply and demand functions by sellers and buyers. White's formula has been used in the calculation of the standard errors since the two step procedure employed in the analysis results in heteroskedastic residuals. The inverse Mills ratio, $\lambda$ is significant in both the sellers and buyers banana market supply and demand equations, indicating that sample selection bias would have resulted if the banana supply and demand equations would have been estimated without consideration of the market participation decision.

Table 3: Banana supply and demand functions by sellers and buyers

\begin{tabular}{|c|c|c|c|c|}
\hline & \multicolumn{2}{|c|}{ Sellers (ln Kgs sold) } & \multicolumn{2}{|c|}{ Buyers (ln Kgs bought) } \\
\hline & Coefficient & $\begin{array}{l}\text { Standard } \\
\text { Error }\end{array}$ & Coefficient & $\begin{array}{l}\text { Standard } \\
\text { Error }\end{array}$ \\
\hline INTERCEPT & $-117.622^{* * *}$ & 39.971 & $-414.031^{* * *}$ & 48.175 \\
\hline ADULTS & $0.268^{* * *}$ & 0.043 & $-0.646^{* * *}$ & 0.057 \\
\hline CHILD5 & -10.333 & 9.432 & 1.471 & 10.947 \\
\hline CHILD17 & $9.841^{*}$ & 5.770 & $-14.023^{* *}$ & 5.905 \\
\hline BEERBANPRI & $0.477^{* * *}$ & 0.022 & 0.020 & 0.054 \\
\hline COOKBANPRI & $0.241^{* * *}$ & 0.023 & 0.101 & 0.121 \\
\hline OFF_FARM & -5.437 & 21.297 & $53.713^{* *}$ & 23.643 \\
\hline ACCESS & $-0.166^{* * *}$ & 0.039 & $-0.120^{* *}$ & 0.051 \\
\hline FSIZE & 0.020 & 0.054 & 0.022 & 0.073 \\
\hline FEMH_WID & $-0.557^{* * *}$ & 0.185 & 0.090 & 0.263 \\
\hline CREDIT & -7.015 & 25.762 & 22.367 & 30.139 \\
\hline YRSEXP & $0.279^{* * *}$ & 0.071 & -0.107 & 0.094 \\
\hline SOILWAT & -30.432 & 36.338 & 51.552 & 42.282 \\
\hline PURC_HIR & $0.061^{* *}$ & 0.028 & $-0.098^{* * *}$ & 0.033 \\
\hline TLU TOT & $-0.187^{* * *}$ & 0.035 & $-0.296^{* * *}$ & 0.042 \\
\hline$\lambda$ & $0.166^{* * *}$ & 0.029 & $-0.117^{* * *}$ & 0.030 \\
\hline R-Squared adjusted & 0.382 & & 0.186 & \\
\hline
\end{tabular}

Note: ${ }^{*}{ }^{* *}$ and ${ }^{* * *}$ denote significance at the 10,5 and $1 \%$ levels respectively

The coefficient for adult members of the household who are full time on farm and children between the ages of 6 and 17 years had a positive sign and significantly different from zero in the banana supply equation for sellers but was negative for the buyers demand equation. An additional adult member of the household raises the quantity of bananas sold by $0.3 \mathrm{Kg}$ and lowers purchase amount by $0.6 \mathrm{Kg}$. This is expected since the adults provide a labor resource base for the production of marketable surplus. 
The price effects for both beer and cooking bananas were positive and significant for sellers and not significant for buyers, suggesting an upward sloping supply curve, supportive of the supply hypothesis. The price elasticities for both beer and cooking bananas are, respectively, $9.6 \%$ and $5.6 \%$ for sellers, suggesting that beer bananas are more responsive to price changes compared to cooking bananas ${ }^{5}$. The market access variable, showing time taken to reach the nearest urban market had a negative and significant influence on both supply and demand quantities for sellers and buyers, showing a decline in banana transacted quantities with increase in time taken to reach the nearest urban market. This variable reflects the influence of transactions costs in terms of distance and cost of information. The results show that farmers located one hour further from the nearest urban market reduce the transacted quantities by $17 \%$ for sellers and $12 \%$ for buyers compared to those living closer to these markets. This result conforms to findings of Alene et al (2008) in the Kenyan maize markets where farmers located far from the market reduce transacted quantities by a substantial $62 \%$.

The coefficient for off farm income was positive and significant for the banana demand model, a result that conforms with expectations that households with access to off farm income have a relatively high purchasing power that would enable them to buy rather than sell. Besides, they may also be involved in substitute high value enterprises rather than bananas, thus motivating them to buy bananas rather than producing surplus for sale. Other personal characteristics also had significant effects on the banana transacted quantities. The effect of female headed household dummy variable was negative and significant for sellers but positive and non-significant for buyers. The plausible explanation for this result is that female household heads are more negatively affected by the transaction costs of searching for buyers, contracting and enforcing a sales transaction as opposed to the male headed households. Likewise as indicated by Woods (2000), female headed households are more likely to be resource constrained in terms of labor and hence resort to markets to meet their deficits.

Years of farming experience had a significant positive effect on transaction quantities for sellers. The intensity of banana sales increases by $28 \%$ for every extra year of farming experience a household gains. This variable not only reflects the accumulation of expertise in farming but is also linked to repeated transactions which in turn reinforces trust and builds networks that a household needs to facilitate market information exchange (Gabre-Madhin, 2001; Putnam, 1995). The coefficient on freehold land tenure system was positive and significant for the sellers and negative for buyers. This suggests that freehold land tenure system may be associated with high banana production and marketable surplus as it represents a secure tenure system in terms of ownership rights. This finding concurs with other studies in rural areas in developing countries that empirically show higher levels of output and technical efficiency for households with freehold land tenure systems associated with title deeds (Kariuki et al., 2008). Hayes et al. (1997), also find that households with security of land tenure invest in production technologies that result in high output. Number of tropical livestock units possessed by households had a significant negative effect on transacted quantities by sellers and buyers, a result that contrasts with expectations. This is probably because households who keep livestock are not involved in banana production.

\footnotetext{
${ }^{5}$ Price elasticity for the semilog function has been calculated as $\partial \ln Q / \partial P^{*} \bar{P}$, that is the coefficient on price multiplied by average price.(Greene, 2003),
} 


\section{Conclusions and Policy Implications}

This article has investigated the impacts of household, farm, market access and locational characteristics on the jointly determined banana market participation decisions and transacted quantities of sellers and buyers in Rwanda and Burundi. Market participation decisions of sellers and buyers are shown to be non independent of each other. Results show that market participation decisions are highly influenced by fixed transaction costs. Transactions costs associated with transportation and market information have significant negative effects on market participation and transacted quantities. Decrease in costs of information and transportation that stem from improvements in road infrastructure and telecommunications services would improve the incentives of market participation and enable the smallholder banana producers reap the benefits associated with banana marketing. The transaction costs of selling bananas could also be reduced through promotion of collective marketing through farmer groups or cooperatives in order to economize on transactions costs, develop market linkages and take advantage of collective bargaining power.

Beer banana prices were found to provide significant incentives for increased supply. The price elasticity for beer banana was $9.6 \%$ compared to $5.6 \%$ for cooking banana. It therefore appears logical to infer that a high beer banana price policy might improve revenue for the producers. However, high producer prices often lead to high consumer prices since these margins are often passed on to the consumers leading to welfare losses. Instead policies that promote efficient value addition of beer bananas should be encouraged as this would result in higher value products leading to improved welfare for both producers and consumers.

Production enhancing and non-price factors such as labor, security of land tenure, and gender of the household head were also found to have significant effects on market participation and transacted quantities. Having a secure tenure system was found to increase banana market supply by $6 \%$. This suggests that policies that aim at encouraging secure tenurial rights through land registration and provision of title deeds may improve the incentives for production of marketed surplus. The result on disaggregation of market participation decision and intensity by gender of the head of the household reveal a negative influence. Households headed by women are likely to have lower banana supplies to the market by a substantial $56 \%$ relative to their male headed counterparts. This suggests that increased targeting of women for market participation may increase the impact of policy interventions that aim at improved market access.

Locational characteristics were found to be especially important in explaining market participation. These characteristics depict differences in agro-climatic conditions necessary for production of agricultural crops. In particular, households located in beer banana growing areas were found to be highly likely to participate in markets as sellers compared to the cooking banana growing zones. This highlights the need to focus on strategies aimed at improved marketing of beer bananas or its products as it provides a potential avenue for improving rural incomes. Current production of banana beer from beer bananas is done low scale at farm level using rudimentary techniques. Promotion of medium to large scale processing through collective action and organized marketing would have potentially high impact on household welfare. 


\section{Acknowledgements}

The help of numerous colleagues in Rwanda and Burundi's national agricultural research systems at the province, district and commune level is gratefully acknowledged. Data editing assistance by Aline Nkurunziza and GIS analyst Hein Bouwmeester is also acknowledged. Funding for this work has been provided by the Directorate General Development Co-operation (DGDC) - Belgium.

\section{References}

Alene, A. D., Manyong, V. M., Omanya, G., Mignouna, H. D., Bokanga, M., Odhiambo, G., 2008. Smallholder market participation under transactions costs: maize supply and fertilizer demand in Kenya. Food Policy 33(4), 318-328.

Bellemare, M. F., and Barrett, C. B., 2006. An Ordered Tobit Model of Market Participation: Evidence from Kenya and Ethiopia. American Journal of Agricultural Economics, 88 (2), $324-337$.

Chowdhury S. K., 2002. Access to information, Transaction costs and Marketing choice of Rural Households between Middlemen and Direct Buyers in Bangladesh. ZEF University of Bonn, Germany.

Coase, R., 1937. The Nature of the Firm. Economica, 4, 386 - 405

de Janvry, A., Fafchamps, M., Sadoulet, E., 1991. Peasant Household Behavior with Missing Markets: Some Paradoxes Explained. Economic Journal, 101(409), 14001417.

Dorward, A., Kydd, J., Poulton, C., 2005. Institutions, Markets and Economic Development: Linking Development Policy to Theory and Praxis. Development and Change, 36(1), 1-25.

Fafchamps, M., 2004. Market Institutions in Sub-Saharan Africa: Theory and Evidence. Cambridge, M.A: MIT Press, pp 23 - 37

Fafchamps, M., Hill, R.V., 2005. Selling at Farmgate or Traveling to Market. American Journal of Agricultural Economics, 87(3), 717 - 734.

Farrow A., Busingye, L., Bagenze, P., 2007. Characterisation of Mandate Areas for the Consortium for Improved Agriculture-based Livelihoods in Central Africa (CIALCA), Project Annual Report.

FAOSTAT, 2008. Food and Agriculture Organization, online statistical database www.fao.org

Gabre-Madhin, E. 2001. Market Institutions, Transaction Costs and Social Capital in the Ethiopian Grain Market. IFPRI Research Report 124, International Food Policy Research Institute, Washington D.C.

Gaidashova, S. V., Okech, S. H. O., Gold, S. Nyagahungu, I., 2005. Why Beer Bananas? The Case for Rwanda. InfoMusa, 14(1), $2-6$. 
Goetz, S. J., 1992. A Selectivity Model of Household Food Marketing Behavior in SubSaharan Africa. American Journal of Agricultural Economics, 74, 444 - 52.

Hayes, J., Roth, M., and Zepeda, L., 1997. Tenure Security, Investment and Productivity in Gambian Agriculture: A Generalized Probit Analysis. American Journal of Agricultural Economics, 79, 369 - 382

Heckman, J. J. 1979. Sample Selection Bias as a Specification Error. Econometrica, 47, 931-59

ILCA (International Livestock Centre for Africa), 1990. Working Paper No 1. Livestock systems research manual, Vol. 1. International Livestock Centre for Africa, Addis Ababa , 287 pp.

Kariuki, D. Ritho, C. Munei, K., 2008. Analysis of the Effect of Land Tenure on Technical Efficiency in Smallholder Crop Production in Kenya. Conference Paper, Tropentag, October 7-9, 2008 "Competition for Resources in a Changing World: New Drive for Rural Development”, Hohenheim, Germany.

Key, N., Sadoulet, E., de Janvry, A., 2000. Transactions Costs and Agricultural Household Supply Response. American Journal of Agricultural Economics 82,24559.

Kranton, R.E., 1996. Reciprocal Exchange: A Self-sustaining System. American Economic Review 86(4), 830 - 851

Kydd, J., and Dorward, A., 2004. Implications of Market and Coordination Failures for Rural Development in Least Developed Countries. Journal of International Development, 16(7), 951 - 970

Maddala, G. S., 1983. Limited-Dependent and Qualitative Variable in Econometrics. Cambridge University Press, Cambridge.

Makhura, M., Kirsten, J., Delgado, C., 2001. Transaction costs and smallholder participation in the maize market in the Northern Province of South Africa. Seventh Eastern and Southern Africa regional Conference, February, pp 463 - 467

Minten, B., Kyle S., 1999. The Effect of Distance and Road Quality on Food Collection, Marketing Margins and Traders' Wage: Evidence from Former Zaire. Journal of Development Economics, 60, 467 - 495.

Omamo, S. W., 1998. Transport costs and Small holder Cropping Choices: An Application to Siaya District, Kenya. American Journal of Agricultural Economics 80, 116-123.

Putnam, R., 1995. Bowling Alone: America's Declining Social Capital. Journal of Democracy 6, 65-78.

Strauss, J., 1986. The Theory and Comparative Statics of Agricultural Household Models: A General Approach, in I. Singh, L. Squire, and J. Strauss, eds. Agricultural Household Models: Extensions, Applications and Policy. pp 71-91. Baltimore MD: John Hopkins University Press, 1986.

Williamson, O. E., 1985. The Economic Institutions of Capitalism. The Free Press, New York. 
Woods, P. S. A., 2000. The importance of proximity, transport, and gender as transaction costs in the use of veterinary services in Zimbabwe. In: Leonard, D. K. (Ed.), Africa's Changing Markets for Health and Veterinary Services: The New Institutional Issues, Macmillan, London , pp. 67-91.

World Bank, 2002. World development report 2002: Building institutions for markets. Oxford University Press, New York. 